5. Moseychuk Yu., Moroz O. (2014), "Interconnection of motor activity level and body mass index and body composition of women in the first period of mature age", Teoriya i metodyka fizychnoho vykhovannya i sportu, No. 2, pp.75-78.

6. President of Ukraine (2016), "On the National Strategy for the Improvement of Motor Activity in Ukraine for the period up to 2025" "Motor Activity - a Healthy Lifestyle - A Healthy Nation", Uriadovyi kur'ier, No. 38, pp. 8-9.

7. Synytsya T, Shesterova L. (2017), "Research of the relevance of lessons on health aerobics for women of the first mature age", Slobozhans'kyy naukovo-sportyvnyy visnyk, No. 6(62), pp. 97-101.

8. Sorokina SO, Kudryashova T.I. (2011), "Motivational interest of women 30-50 years of age in pursuit of health improvement exercises", Problemy fizychnoho vykhovannya i sportu, No. 6, pp. 123-125.

9. Bouchard C, Shephard R, Stephens T. (1994), "Physical activity, fitness, and health", Champing, IL: Human Kinetics, p. 25-41.

10. Corbin CB. (2002), "Physical activity for everyone: What every physical educator should know about promoting lifelong physical activity", Journal Teacher in Physical Education, No. 21, pp. 128-144.

11. Strohle A. (2009), "Physical activity, exercise, depression and anxiety disorders", Journal of neural transmission, No. 116, pp. 777-784.

Цитування на цю статтю:

Ріпак МO. Ріпак IM. Особливості рухової активності жінок. Вісник Прикарпатського університету. Серія: Фізична культура. 2019 Берез 26; 33: 72-78

\begin{tabular}{|c|c|}
\hline Відомості про автора: & Information about the author: \\
\hline $\begin{array}{l}\text { Ріпак Мар'яна Олексї̈на - кандидат наук з фі- } \\
\text { зичного виховання і спорту, доцент, Львівський } \\
\text { державний університет фізичної культури ім. Івана } \\
\text { Боберського (Львів, Україна) }\end{array}$ & $\begin{array}{l}\text { Ripak Mariana Oleksiivna - Candidate of Science } \\
\text { (Physical Education and Sport), Associate Professor } \\
\text { (Ph. D.), Lviv State University of Physical Culture } \\
\text { (Lviv, Ukraina) }\end{array}$ \\
\hline \multicolumn{2}{|l|}{$\begin{array}{l}\text { e-mail: m.ripak.27@ gmail.com } \\
\text { https://orcid.org/0000-0002-2799-8726 }\end{array}$} \\
\hline $\begin{array}{l}\text { Pіпак Ігор Миронович - кандидат наук з фізичного } \\
\text { виховання і спорту, доцент, Львівський державний } \\
\text { університет фізичної культури ім. Івана Бобер- } \\
\text { ського (Львів, Україна) }\end{array}$ & $\begin{array}{l}\text { Ripak Ihor Myronovych - Candidate of Science } \\
\text { (Physical Education and Sport), Associate Professor } \\
\text { (Ph. D.), Lviv State University of Physical Culture } \\
\text { (Lviv, Ukraina) }\end{array}$ \\
\hline $\begin{array}{l}\text { e-mail: ihor_ripak@ukr.net } \\
\text { https://orcid.org/0000-0002-8210-7420 }\end{array}$ & \\
\hline
\end{tabular}

УДК 378.018.43

doi: 10.15330/fcult.33.78-84

Оксана Савонова

\title{
ПРИРОДНИЧО-НАУКОВА ПІДГОТОВКА МАЙБУТНІХ ФАХІВЦІВ ФІЗИЧНОГО ВИХОВАННЯ І СПОРТУ З ВИКОРИСТАННЯМ ТЕХНОЛОГІЙ ЗМІШАНОГО НАВЧАННЯ
}

\begin{abstract}
Мета. Розглянути особливості та переваги реалізації природничо-наукової підготовки майбутніх фахівців з фізичного виховання і спорту з використанням технологій зміманого навчання. Методи. У дослідженні використовувалися методи теоретичного та емпіричного дослідження: аналізу, синтезу та узагальнення результатів авторського досвіду ефективного використання технологій змішаного навчання дисциплін природничо-наукового напрямку підготовки майбутніх фахівиів фізичної культури та спорту на базі кафедри біологічних основ фізичного виховання, здоров'я $і$ спорту Національного університету “Чернігівський колегіум” імені Т.Г. Шевченка. Результати. обтрунтовують необхідність створення науково-методичного иентру або лабораторії технологій зміманого навчання на базі кафедри біологічних основ фізичного виховання, здоров'я і спорту. Основними напрямками діяльності такого иентру або лабораторії визначено: забезпечення інтеграції технологій зміманого навчання в освітній процес факультетів фізичного виховання з метою підвищення його якості та ефективності; забезпечення консультаційно-методичної підтримки науково-педагогічних прачівників та проведення відповідних заходів щуодо підвищення їх рівня знань, умінь та навиків з питань практичної реалізацїі
\end{abstract}


змішаного навчання на всіх етапах; забезпечення організаційно-методичної підтримки зі створення та систематичного оновлення електронної інформаційної системи відкритого доступу навчальнометодичного забезпечення організації змішаного навчання природничо-наукових дисциплін; розробка та наукове обтрунтування теоретичних і методичних засад ефективного використання технологій змішаного навчання в освітньому прочесі; пошук та дослідження нових шляхів і програмно-технічних рішень підвищення ефективності змішаного навчання (створення та використання освітнього контенту, забезпечення ефективної взаємодії між його учасниками); моніторинг дотримання нормативних вимог щзодо створення навчально-методичного забезпечення та організації змішаного навчання, а також проведення експертної оцінки якості изього процесу на всіх його етапах. Висновок. Доведено необхідність створення науково-методичного иентру або лабораторії технологій зміманого навчання на базі кафедри біологічних основ фізичного виховання, здоров'я $і$ спорту, щзо допоможе забезпечити якість природничо-наукової підготовки майбутніх фахівців з фізичного виховання $і$ спорту в умовах реформування вищої освіти Украӥни.

Ключові слова: майбутні фахівиі з фізичного виховання і спорту, природничо-наукова підготовка, технологї̈ змішаного навчання.

The purpose of the work is to consider the peculiarities and advantages of the natural and scientific preparation of future specialists in physical education and sports using blended learning technologies. The research methods are based on the application of methods of analysis, synthesis and generalization of the results of author's experience effective use blended learning technologies at the Department of Biological Basis of Physical Training, Health and Sports of the T.H. Shevchenko National University "Chernihiv Colehium" (NUCHK). The results of the research substantiate the necessity of creating a scientific-methodical centre or a laboratory of blended learning technologies based on the Department of Biological Foundations of Physical Education, Health, and Sports. The main areas of activity of the scientific-methodical centre or of the laboratory of blended technologies are: ensuring the integration of blended learning technologies into the educational process of the physical training faculties in order to improve its quality and effectiveness; providing consulting and methodological support to scientific and pedagogical workers and carrying out appropriate measures to increase their level of knowledge, skills and acquired habits on the practical implementation of blended learning at all stages; provision of organizational and methodological support for the creation and systematic updating of the electronic information system of open access to the teaching and methodological support for the organization of blended learning of natural sciences disciplines; development and scientific substantiation of theoretical and methodical principles of effective use of technologies of blended learning in the educational process of institutions of higher education; search and research of new ways, software and technical solutions to increase the effectiveness of blended learning (creation and use of educational content, ensuring effective interaction between its participants); monitoring compliance with regulatory requirements for the creation of teaching and methodological support and the organization of blended learning, as well as expert evaluation of the quality of this process at all its stages. Conclusion: the article proves the necessity of creating a scientificmethodical centre or laboratory of blended learning technologies based on the Department of Biological Foundations of Physical Education, Health and Sports, which can help to provide high-quality natural and scientific preparation of future specialists in physical education and sports in the context of the reforming of higher education in Ukraine.

Key words: future specialists in physical education and sports, natural and scientific preparation, blended learning technologies.

Постановка проблеми й аналіз результатів останніх досліджень: Змішане навчання та його реалізація в сучасних умовах модернізації освіти України є актуальним і перспективним питанням у рамках організації освітнього процесу як закладів середньої так і вищої освіти. На це вказують науковці В. Л. Бузько, Г. М. Дзіман, В. В. Коткова та ін. $[1,2,3]$.

Особливо актуальним це питання постає під час організації природничо-наукової підготовки майбутніх фахівців фізичної культури і спорту, яка спрямована забезпечити формування у студентів здоров'язбережувальних компетентностей. Адже саме від іiі ефективності та якості залежить ефективність розвитку здоров'язбережувального потенціалу України - формування у кожного ії громадянина усвідомленого дотримання та поширення стандартів здорового способу життя як умови забезпечення його якості.

Організація природничо-наукової підготовки фахівців у закладах вищої освіти $\epsilon$ ресурсозатратним процесом і потребує наявності й постійного оновлення як мате- 
ріально-технічної бази (лабораторного обладнання, реактивів, комп'ютерної техніки тощо), так і навчально-методичного забезпечення освітнього процесу із врахуванням стратегічних завдань реформування вищої освіти України $[4,5]$.

Мета дослідження - розглянути особливості та переваги реалізації природничонаукової підготовки майбутніх фахівців 3 фізичного виховання і спорту 3 використанням технологій змішаного навчання.

Методи й організація дослідження. У дослідженні використовувалися методи теоретичного та емпіричного дослідження: аналізу, синтезу та узагальнення результатів авторського досвіду ефективного використання технологій змішаного навчання дисциплін природничо-наукового напрямку підготовки майбутніх фахівців фізичної культури та спорту на базі кафедри біологічних основ фізичного виховання, здоров'я i спорту Національного університету “Чернігівський колегіум” імені Т.Г.Шевченка.

Результати і дискусія. Пошук ефективних шляхів реалізації змішаного навчання дисциплін природничо-наукової підготовки майбутніх фахівців фізичної культури i спорту розпочато на кафедрі біологічних основ фізичного виховання, здоров'я і спорту відповідно до ключових стратегічних цілей визначених у Статуті та Стратегії розвитку Національного університету “Чернігівський колегіум” імені Т.Г.Шевченка на 20162021 роки. Серед них: запровадження системного використання інформаційно-комунікаційних технологій в освітньому процесі та дистанційної форми навчання 3 метою створення відкритого освітнього, дослідницького та інформаційного простору з підготовки фахівців нового покоління, з новітнім спектром знань та компетентностей, конкурентноспроможних на сучасному ринку праці $[6,7]$.

Відповідно до цього, з метою забезпечення неперервності, гнучкості та якості вивчення дисциплін природничо-наукового циклу підготовки майбутніх фахівців фізичної культури спорту, була розгорнута робота зі створення електронних навчальних курсів дисциплін кафедри БОФВЗС. Зокрема, починаючи з 2016 року, в системі Moodle (https://moodle.chnpu.edu.ua) створено електронні навчальні курси з таких дисциплін як: "Біохімія”, “Основи медичних знань”, “Фізіологія людини”, “Фізіологія рухової діяльності”, “Основи психовалеологіі”, “Психофізіологія”, “Фізіологічні основи адаптації до м'язової діяльності”, “Методологія збереження та зміцнення здоров'я”, “Інноваційні технології в освіті”. А з лютого 2017 року започаткована їх апробація в СУН Moodle впродовж навчальних семестрів відповідно до діючого освітнього плану підготовки майбутніх фахівців фізичної культури і спорту. Цей процес охоплює студентів усіх курсів бакалаврського і магістерського рівня підготовки з обов'язковою їх реєстрацією в СУН Moodle. Він також передбачає проведення подальшого аналізу і вдосконалення як електронних навчальних курсів так і методики використання технологій змішаного навчання в освітньому процесі.

У результаті аналізу результатів освітньої діяльності та проведення усних бесід 3 викладачами і студентами визначено такі позитивні моменти застосування технологій змішаного навчання на кафедрі біологічних основ фізичного виховання, здоров'я i спорту НУЧК імені Т.Г. Шевченка.

По-перше, використання технологій змішаного навчання - це здатність забезпечити індивідуалізацію освітнього процесу. Це можливість своєчасно виокремити студентів, які щось не зрозуміли в процесі освоєння навчального матеріалу дисципліни і негайно відреагувати, коректуючи їх освітню траєкторію завдяки очному спілкуванню так і в он-лайн форумах СУН Moodle. Завдяки такому індивідуальному особистісноорієнтованому підходу, покращується мотивація студентів до більш інтенсивної самостійної роботи. А оптимально підібрана навчальна інформація, яку потрібно проаналізувати і засвоїти й необхідні для виконання практичні завдання різних рівнів склад- 
ності від відтворення до створення чогось нового, допомагають студенту навчитися критично мислити, самостійно планувати власну освітню діяльність, контролювати i регулювати iї, об'єктивно оцінюючи власні можливості і тим самим особисто розвиваючись.

По-друге, завдяки використанню електронних навчальних курсів в освітньому процесі підготовки фахівців фізичної культури та спорту з можливістю автоматизувати проведення різних видів контролю та виконання завдань щодо пошуку і застосування нової інформації на задану тематику, у викладача з'являється можливість зекономити час на етапах пояснення та контролю навчальних досягнень 3 окремої теми. I тим часом сконцентрувати свою діяльність на організацію формування та відпрацювання на заняті практичних навиків з дисципліни. А також долучити до освітнього процесу значно більшу кількість студентів групи, навіть тих кого не було на попередньому занятті тобто підвищити масовість навчання.

По-третє, на думку студентів, заняття стали більш цікавішими і швидкоплинними у порівнянні з тими, на яких технології змішаного навчання не застосовуються. Адже вони проводяться у формі гри, змагань, дискусій, квестів чи презентацій результатів навчальних проектів. Подобається, що надається можливість користуватися мобільними телефонами на парі для швидкого пошуку потрібної інформації в Інтернеті. Що не потрібно конспектувати багато інформації на занятті, а можна їі прочитати або подивитися на курсі в системі Moodle. Подобається, що дозволяється висловлювати свої думки щодо вирішення поставлених проблем або спірних питань, доводити їх іншим, шукати командою вирішення нестандартних задач, готувати та презентувати доповіді, перемагати і отримувати від цього задоволення.

Нажаль, під час реалізації природничо-наукової підготовки майбутніх фахівців фізичної культури і спорту з використанням технологій змішаного навчання виникають також і труднощі, які можуть супроводжувати цей процес.

Одними 3 них, є труднощі пов'язані з недостатністю необхідного досвіду у науково-педагогічних працівників створювати, редагувати та постійно оновлювати електроні навчальні курси з дисциплін, які вони ведуть та забезпечувати практичну реалізацію змішаного навчання студентів. А тому деякі викладачі просто не мають бажання взагалі переходити на нову форму організації освітнього процесу і віддають перевагу в своїй роботі традиційній взаємодії зі студентами. Цілком слушно, що потрібно забезпечити можливість підвищення рівня знань, умінь та навичок викладачів з питань практичної реалізації змішаного навчання дисциплін природничо-наукового напряму. I навчити їх використовувати у своїй діяльності інноваційні технології (інформаційно-комунікативні, дистанційні, хмарні, електронні, мобільні, інтерактивні, тренінгові, проектні тощо) так, щоб вони доповнювали одна одну і працювали як одне ціле в підготовці майбутніх фахівців, зокрема фахівців фізичної культури, спорту і здоров'я.

Були виявлені труднощі, які здатні взагалі нівелювати усі напрацювання щодо реалізації змішаного навчання. Це так звані “форс-мажорні” ситуації, пов’язані з технічним і програмним забезпеченням Інтернет-зв'язку в університеті та функціонування серверу, де розміщується СУН Moodle. Задля попередження виникнення таких явищ потрібно обгрунтувати і відпрацювати оптимальні шляхи взаємодії між окремими кафедрами або факультетами та адміністративним відділом, що забезпечує матеріальнотехнічний супровід освітнього процесу ЗВО з використанням комп'ютерних та мережевих технологій із можливим захистом інформації.

Разом із тим, вирішення потребують питання відпрацювання процедури стандартизації та експертної оцінки електронних навчальних курсів як навчально-методичного забезпечення дисциплін на рівні кафедри та на рівні університету, а також забезпечення 
ефективності їх системного використання в освітньому процесі 3ВО. Адже на практиці продовжують зустрічатися випадки з використання в тестах електронних навчальних курсів тестових завдань лише репродуктивного рівня або завдань із так званими підказками, закладених у варіанти відповідей до них. Разом із тим, $є$ курси з подачею лише довідникової інформації з дисципліни без будь-якого забезпечення проведення активізації навчальної діяльності студентів чи навіть контролю їх навчальних досягнень.

Тому, з метою вирішення зазначених проблем та своєчасного реагування на глобальні виклики, зміни умов і обставин на ринку надання освітніх послуг й ефективної побудови взаємовідносин між студентами та викладачами на принципах індивідуалізації, оптимізації, інтенсифікації, толерантності та партнерства, шляхом упровадження в освітній процес НУЧК імені Т.Г.Шевченка змішаного навчання, на базі кафедри біологічних основ фізичного виховання здоров'я і спорту має бути створений відповідний науково-методичний центр або лабораторія технологій змішаного навчання.

Основними напрямками діяльності такого центру або лабораторії технологій змішаного навчання мають стати:

1. Забезпечення інтеграції змішаного навчання в освітній процес НУЧК імені Т.Г.Шевченка, зокрема освітній процес факультету фізичного виховання з метою підвищення якості та ефективності підготовки майбутніх фахівців, зокрема майбутніх фахівців фізичної культури, та спорту.

2. Забезпечення консультаційно-методичної підтримки науково-педагогічних працівників НУЧК імені Т.Г.Шевченка щодо організації освітнього процесу закладу вищої освіти з використанням технологій змішаного навчання та систем управління навчання, у тому числі СУН Moodle на всіх його етапах і формах під час природничо-наукової підготовки майбутніх фахівців фізичної культури та спорту.

3. Проведення, відповідно до плану роботи лабораторії, навчально-методичних семінарів та тренінгів щодо підвищення рівня знань, умінь та навичок науково-педагогічних працівників з питань практичної реалізації змішаного навчання дисциплін природничо-наукового напряму на всіх його етапах від створення навчально-методичного забезпечення організації змішаного навчання до перевірки його якості та використання при підготовці майбутніх фахівців зокрема, майбутніх фахівців фізичної культури та спорту.

4. Організаційно-методична підтримка зі створення та систематичного оновлення електронної інформаційної системи відкритого доступу навчально-методичного забезпечення організації змішаного навчання дисциплін кафедри (електронних навчальних курсів, комплексів для перевірки якості підготовки фахівців тощо).

5. Розробка та наукове обгрунтування теоретичних і методичних засад ефективної реалізації технологій змішаного навчання в освітньому процесі закладу вищої освіти, у тому числі під час природничо-наукової підготовки майбутніх фахівців фізичної культури та спорту

6. Пошук, дослідження та впровадження нових шляхів підвищення ефективності змішаного навчання - шляхів організації необхідної взаємодії між його учасниками, а також нових програмно-технічних рішень щодо створення й використання освітнього контенту реалізації змішаного навчання на практиці.

7. Моніторинг дотримання нормативних вимог щодо створення навчально-методичного забезпечення та організації змішаного навчання, а також проведення експертної оцінки якості цього процесу на всіх його етапах.

Зазначені напрямки діяльності здатні органічно доповнити основні види завдань плану роботи кафедри біологічних основ фізичного виховання здоров'я Національного університету “Чернігівський колегіум” імені Т.Г.Шевченка. 


\section{Висновок}

Розглянуті вище особливості реалізації природничо-наукової підготовки майбутніх фахівців з фізичного виховання і спорту з використанням технологій змішаного навчання обгрунтовують необхідність створення науково-методичного центру або лабораторії технологій змішаного навчання на базі кафедри біологічних основ фізичного виховання, здоров'я і спорту, яка здатна допомогти забезпечити якісну природничо-наукову підготовку майбутніх фахівців з фізичної культури і спорту в умовах реформування вищої освіти України. Основними напрямками діяльності такого центру або лабораторії визначено: забезпечення інтеграції технологій змішаного навчання в освітній процес факультетів фізичного виховання 3 метою підвищення його якості та ефективності; забезпечення консультаційно-методичної підтримки науково-педагогічних працівників та проведення відповідних заходів щодо підвищення їх рівня знань, умінь та навиків з питань практичної реалізації змішаного навчання на всіх етапах; забезпечення організаційно-методичної підтримки зі створення та систематичного оновлення електронної інформаційної системи відкритого доступу навчально-методичного забезпечення організації змішаного навчання природничо-наукових дисциплін; розробка та наукове обгрунтування теоретичних і методичних засад ефективного використання технологій змішаного навчання в освітньому процесі; пошук та дослідження нових шляхів і програмно-технічних рішень підвищення ефективності змішаного навчання (створення та використання освітнього контенту, забезпечення ефективної взаємодії між його учасниками); моніторинг дотримання нормативних вимог щодо створення навчально-методичного забезпечення та організації змішаного навчання, а також проведення експертної оцінки якості цього процесу на всіх його етапах.

Перспективними напрямками подальших досліджень вбачаємо реалізацію зазначених вище напрямків роботи науково-методичного центру або лабораторії технологій змішаного навчання, а також створення концепції та методичної системи реалізації змішаного навчання природничо-наукових дисциплін майбутніх фахівців фізичного виховання та спорту.

1. Бузько ВЛ. Змішане навчання фізики в загальноосвітній школі в умовах комп'ютерно-орієнтованого середовища навчання. Збірник наукових праць Кам'янець-Подільського Національного університету імені Івана Огієнка. Серія педагогічна. [Інтернет]. 2016 [цитовано 2019 лют. 24]; (Вип. 22, Дидактичні механізми дієвого формування компетентнісних якостей майбутніх фахівців фізико-технологічних спеціальностей): 72-4. Доступно 3: http://journals.uran.ua/index.php/2307-4507/article/download/ 94588/90221.

2. Дзіман ГМ. Моделювання змішаного навчання майбутніх інженерів-біотехнологів академічного письма англійською мовою. Вісник Чернігівського національного педагогічного університету. Серія: Педагогічні науки. [Інтернет]. 2016 [цитовано 2019 лют. 24]; (141): 58-62. Доступно з: http://nbuv.gov.ua/UJRN/VchdpuP_2016_141_16.

3. Коткова ВВ. Реалізація курсу змішаного навчання майбутніх учителів початкових класів . Інформаційні технології і засоби навчання. [Інтернет]. 2017. [цитовано 2019 лют. 25]; 60(4): 312-23. Доступно 3: http://nbuv.gov.ua/UJRN/ITZN_2017_60_4_27.

4. Білецька Г. Обгрунтування концепції природничо-наукової освіти майбутніх екологів. Педагогіка $\mathrm{i}$ психологія професійної освіти [Інтернет]. 2014 [цитовано 2019 Лют. 25]; 1: 37-46. Доступно з: http://nbuv.gov.ua/UJRN/Pippo_2014_1_5.

5. Фастівець А, Хоменко П. Природничо-наукова підготовка майбутнього фахівця фізичної реабілітації як педагогічна проблема. Витоки педагогічної майстерності. [Інтернет]. 2016 [цитовано 2019 лют. 25]; (18): 362-6 Доступно 3: http://dspace.pnpu.edu.ua/bitstream/123456789/7745/1/Fastivets.pdf.

6. Статут Національного університету “Чернігівський колегіум” імені Т.Г.Шевченка [Інтернет]. 2018 [цитовано 2019 лют. 27]. 33 с. Доступно 3: https://drive.google.com/file/d/1oA5aM7ijvQqUCXCH8igh NqykWQY_v97W/view.

7. Стратегії розвитку Чернігівського національного педагогічного університету імені Т.Г. Шевченка на 2016-2021 роки [Інтернет]. 2016 [цитовано 2019 лют. 27]. 19 с. Доступно 3: https://drive.google. com/file/d/0ByJ_WEFXldX_Wjc2aFFsZ09idW8/view. 


\title{
References
}

1. Buzko VL. Zmishane navchannia fizyky $\mathrm{v}$ zahalnoosvitnii shkoli $\mathrm{v}$ umovakh kompiuterno-oriientovanoho seredovyshcha navchannia. Zbirnyk naukovykh prats Kamianets-Podilskoho Natsionalnoho universytetu imeni Ivana Ohiienka. Seriia pedahohichna. [Internet]. 2016 [tsytovano 2019 liut. 24]; (Vyp. 22, Dydaktychni mekhanizmy diievoho formuvannia kompetentnisnykh yakostei maibutnikh fakhivtsiv fizykotekhnolohichnykh spetsialnostei): 72-4. Dostupno z: http://journals.uran.ua/index.php/2307-4507/article/ download/94588/90221

2. Dziman HM. Modeliuvannia zmishanoho navchannia maibutnikh inzheneriv-biotekhnolohiv akademichnoho pysma anhliiskoiu movoiu. Visnyk Chernihivskoho natsionalnoho pedahohichnoho universytetu. Seriia: Pedahohichni nauky. [Internet]. 2016 [tsytovano 2019 liut. 24]; (141): 58-62. Dostupno z: http://nbuv.gov.ua/UJRN/VchdpuP_2016_141_16.

3. Kotkova VV. Realizatsiia kursu zmishanoho navchannia maibutnikh uchyteliv pochatkovykh klasiv . Informatsiini tekhnolohii i zasoby navchannia. [Internet]. 2017. [tsytovano 2019 liut. 25]; 60(4): 312-23. Dostupno z: http://nbuv.gov.ua/UJRN/ITZN_2017_60_4_27.

4. Biletska H.Obgruntuvannia kontseptsii pryrodnycho-naukovoi osvity maibutnikh ekolohiv. Pedahohika i psykholohiia profesiinoi osvity [Internet]. 2014 [tsytovano 2019 Liut. 25]; 1: 37-46. Dostupno z: http://nbuv.gov.ua/UJRN/Pippo_2014_1_5.

5. Fastivets A, Khomenko P. Pryrodnycho-naukova pidhotovka maibutnoho fakhivtsia fizychnoi reabilitatsii yak pedahohichna problema. Vytoky pedahohichnoi maisternosti. [Internet]. 2016 [tsytovano 2019 liut. 25]; (18): 362-6 Dostupno z: http://dspace.pnpu.edu.ua/bitstream/123456789/7745/1/Fastivets.pdf.

6. Statut Natsionalnoho universytetu "Chernihivskyi kolehium" imeni T.H.Shevchenka [Internet]. 2018 [tsytovano 2019 liut. 27]. 33 c. Dostupno z: https://drive.google.com/file/d/1oA5aM7ijvQqUCX CH8ighNqykWQY_v97W/view.

7. Stratehii rozvytku Chernihivskoho natsionalnoho pedahohichnoho universytetu imeni T.H. Shevchenka na 2016-2021 roky [Internet]. 2016 [tsytovano 2019 liut. 27]. 19 c. Dostupno z: https://drive.google.com/file/ d/0ByJ_WEFXldX_Wjc2aFFsZ09idW8/view.

\section{Цитування на цю статтю:}

Савонова OB. Природничо-наукова підготовка майбутніх фахівців фізичного виховання і спорту 3 використанням технологій змішаного навчання. Вісник Прикарпатського університету. Серія: Фізична культура. 2019 Берез 26; 33: 78-84

\begin{tabular}{|c|c|}
\hline Відомості про автора: & Information about the author: \\
\hline $\begin{array}{l}\text { Савонова Оксана Вікторівна - кандидат педа- } \\
\text { гогічних наук, доцент, Національний університет } \\
\text { "Чернігівський колегіум" імені Т.Г.Шевченка (Чер- } \\
\text { нігів, Україна) }\end{array}$ & $\begin{array}{l}\text { Savonova Oksana Viktorivna - Candidate of Science } \\
\text { (Education), Associate Professor (Ph. D.), Taras Shev- } \\
\text { chenko National University "Chernihiv Collegium" } \\
\text { (Chernihiv, Ukraina) }\end{array}$ \\
\hline $\begin{array}{l}\text { e-mail: oksango@gmail.com } \\
\text { https://orcid.org/0000-0002-6072-9181 }\end{array}$ & \\
\hline
\end{tabular}

\section{УДК 37.037}

doi: 10.15330/fcult.33.84-89

\author{
Sinziana Calina Silisteanu, Andrei Emanuel Silisteanu
}

\section{THE IMPORTANCE FOR YOUNG ADULTS TO DO PHYSICAL ACTIVITIES FOR A HEALTHY LIFESTYLE}

Взаємозв'язок між фізичною активністю і станом здоров'я є дуже складним, оскільки фізична активність приносить користь здоров'ю, рух необхідний для правильного функціонування людського організму. На фізичну активність, фізичний стан і стан здоров'я впливають генетичні фактори, умови навколишнього середовища і спосіб життя кожного індивіда. Метою дослідження було виявлення функціонального стану кардіо-респіраторної системи студентів. Була протестована кардіо-респіраторна система на 30 студентах 1-го курсу кафедри здоров'я та розвитку людини віком 18-40 років, які дали свою згоду на участь в експерименті. У дослідженні був використаний тест Руф'є для оцінки функціонального стану дихальної та серцево-судинної систем. Результати дослідження показали, щзо студенти мають хороший фізичний стан, оскільки вони виконують щуоденну серію фізичних вправ 